Kirja-arvio

\title{
Kiinnostaako tila ja materiaalisuus?
}

\author{
Donner, Julia, Hanna Johansson ja Emma Lilja (toim.). 2020. Ikkunalla. \\ Näkymiä sukupuoleen, tilaan ja aikaan. Kirsi Saarikankaan juhlakirja. \\ Taidehistoriallisia tutkimuksia 51. Helsinki: Taidehistorian seura. 125 sivua.
}

\author{
Heidi Haapoja-Mäkelä
}

$\mathrm{F}$ olkloristiikkaa on perinteisesti pidetty teksteihin ja representaatioihin keskittyneenä tieteenalana. Pitkään asia on näin ollutkin varsinkin Suomen alueella, ja tekstien analyysissa folkloristit ovat olleet erinomaisen hyviä. Toisaalta tekstikeskeisyys on vain yksi osa folkloristiikan kenttää: amerikkalaislähtöinen performanssintutkimus ja toisaalta etnografisen kenttätyön mukanaan tuomat näkökulmat ovat jo vuosikymmeniä suunnanneet huomiota myös kielellisen ulkopuoliseen ja esityksellisen ylittävään kuten ilmeisiin, eleisiin ja aisteihin.

Saattaa olla, että on hieman harhaanjohtavaa ja ylimitoitet-

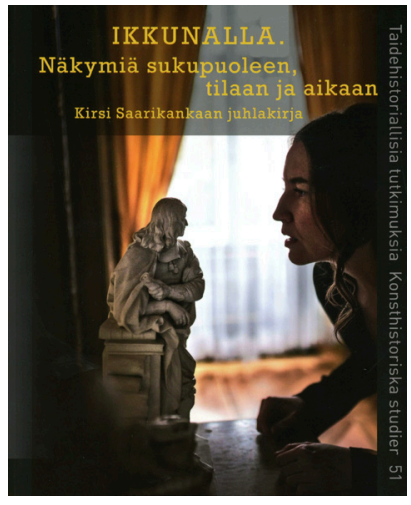
tua kiinnittää huomiota tutkimuksen tavoissa ja lähtökohdissa tapahtuviin muutoksiin, kun voisi tarkastella samuuksiakin. Viimeisten vuosien aikana on kuitenkin alkanut näyttää siltä, että muilla humanistisilla ja yhteiskuntatieteellisillä aloilla huomiota saaneet laajat tieteelliset "käänteet" ovat saavuttaneet suomalaisen folkloristiikan varsin isolla volyymilla. Esimerkiksi affektiivisuus, kehollisuus/ruumiillisuus, materiaalisuus ja spatiaalisuus näkyvät ja tuntuvat jo pelkästään Eloren viimeisimpien numeroiden artikkeleita (esim. Aula 2018; Korjonen-Kuusipuro \& Kuusisto-Arponen 2017; Savolainen et al. 2020; Tolvanen \& Laakkonen 2018) ja katsauksia (Ojanen 2018; Suopajärvi et al. 2019) selailemalla. Näitä näkökulmia voisi varmaankin kutsua "muodikkaiksi", mutta tämä olisi ylenkatsovaa ja lyhytnäköistä. Yhteiskuntatieteiden aloilla nämä käänteet ovat monelta osin jo usean vuosikymmenen ikäisiä, ja niiden taakse on kertynyt paljon vaikuttavaa tutkimusta. Affektit, kehot, materiat ja tilat ovat täällä, ja folkloristiikankin on tietysti otettava niihin kantaa tekstien ohella - pysyäkseen elinvoimaisena.

Osin tästä syystä tartuin professori Kirsi Saarikankaan Ikkunalla-juhlakirjaan. Ajattelin artikkelikokoelman tuovan laajasti esille uusimpia lähialoilla käytettyjä metodeja ja teoreettisia lähtökohtia, sillä taidehistorioitsija Saarikangas tunnetaan Suomessa tärkeänä vaikuttajana ja ajattelijana monitieteisessä tilan tutkimuksen kentässä. Hänen tutkimuksensa ovat keskittyneet esimerkiksi eletyn tilan, sukupuolen, kaupungin, lähiön ja kodin dynamiikkoihin (esim. Saarikangas 2006). Ikkunalla-artikkelikokoelma sisältää Saarikankaan kollegoiden 
kirjoittamia vertaisarvioituja ja arvioimattomia tekstejä, joista suuri osa asettuu taidehistorian tutkimuksen kenttään. Osa artikkeleista tulee myös taidehistorian ulkopuolelta, ja monet kirjoittajista ovat varsin nimekkäitä kotimaisia ja kansainvälisiä tutkijoita.

\section{Siltoja, tunnetta, liikettä, epäjärjestystä}

Useat juhlakirjan artikkelit tarkastelevat representaation, tilan, materian ja kokemuksen välisiä solmukohtia ja rajapintoja. Tämä ei ole mikään ihan helposti selvitettävä ja kesytettävä kenttä: aihe vaatii monenlaisia metodisia otteita, ja Ikkunalla-kokoelman artikkeleissa sovelletaankin useita näkökulmia. Tarkastelen tässä juhlakirjan artikkeleista sellaisia, joilla on mahdollisesti jotakin annettavaa folkloristiikan ja lähialojen tutkimukselle ja joiden metodinen pohdinta representaation, tilan, materian ja kokemuksen välisistä suhteista on mielestäni sujuvaa ja onnistunutta.

Maunu Häyrysen katsaushenkinen "Kiikari väärinpäin?" -artikkeli käsittelee kokemuksen ja (maisema)representaation välisen suhteen teoretisointia. Hän tuo yhteen aiempaa konstruktivistista tapaa tulkita esimerkiksi maisemakuvastoa yhteiskunnallisena representaationa sekä uusimpia esityksellisyyden ylittäviä (more-than-representational) näkökulmia tilan ja maiseman kokemiseen. Häyrysen artikkelin anti on näiden teoreettisten otteiden välille muodostuvan sillan rakentaminen: hän hakee työkaluja, joilla molemmat lähtökohdat voitaisiin ikään kuin kaksoisontologisesti ottaa huomioon. Häyrynen pohdiskelee, miksi esimerkiksi pääosin 1800-luvulta kumpuavat "kansallismaisemiksi" ymmärretyt maisemaesitykset saavat yhä aikaan sen, että ihmiset matkailevat vaikkapa Kolille ja jakavat Instagramissa täsmälleen samantapaisia kuvia kuin karelianistitaiteilijat tuottivat 100 vuotta sitten. Hän puhuu "representaatioiden kaksisuuntaisuudesta" ja esittää, että "ihmiset eivät vain tunnista omia paikkojaan ja kokemuksiaan kuvastosta vaan moniaistiset ja ruumiilliset paikkakokemukset voivat itsessään olla kuvaston kansallista tilaa kuvittaviksi tarinoiksi järjestämien ja tunnekoodaamien representaatioiden esittämisen väline" (s. 54). Tällainen ajattelutapa voisi avata uusia mahdollisuuksia esimerkiksi sen ymmärtämiseen, miksi Kalevala edelleen on niin hartaasti yhä uudelleen tulkittu ja merkityksellistetty. Häyrystä mukaillen voidaan ajatella, että Kalevalaan liittyvät, jo kauan yhteiskunnassa kiertäneet nationalistisesti sävyttyneet diskurssit muuntuvat tunnekoodatuiksi moniaistisessa tulkintaprosessissa. Tällöin kokemus Kalevalan merkityksellisyydestä syntyy diskurssien, affektiivisten kokemusten ja materian vastavuoroisessa suhteessa.

Hieman toisesta näkökulmasta samantyylistä representaation ja eletyn tilan välistä dynamiikkaa käsittelee myös Susanna Santala, joka tarkastelee arkkitehti Viljo Revellin suunnittelemaa Toronton kaupungintaloa osana kaupungin infrastruktuuria. Hän hyödyntää muun muassa toimijaverkkoteoriaa, jossa huomioidaan toisiinsa vaikuttavat inhimilliset ja ei-inhimilliset tekijät ja näiden liike. Santala ei siis tarkastele kaupungintaloa arkkitehtonisena monumenttina, vaan kudelmana, jota määrittävät kaupunkiympäristö ja eletyt tilat. Arkeologi Tuija Kirkinen sen sijaan vie lukijan konkreettisesti Helsingin maaperään, jota hän katselee hybridiluonnon käsitteen näkökulmasta. Käsitteen avulla hän havainnollistaa sitä, että kulttuuri ja luonto eivät ole toisistaan erillisiä entiteettejä, vaan aina hybridisesti toisiinsa kietoutuneita. Helsingin maaperä toimii artikkelissa esimerkkinä, ja Kirkinen kuvaa kiinnostavalla ja silmiä avaavalla tavalla, miten ydinkeskustassa kulkevan tavallisen tallaajan askelten alla on menneiden aikojen muistumina kerroksia, joissa on kuivatetun merenrannan jäljiltä risuja, hiekkaa, rakennusaineita, jätteitä, ulosteita, täytemaata ja niin edelleen. 
Nämä kerrokset eivät näy katukuvassa harjaantumattomalle silmälle, mutta muodostavat merkittävän ulottuvuuden paikan historiallisen ja materiaalisen luonteen ymmärtämiselle. Molemmat artikkelit tarjoavat mielenkiintoisia metodologisia lähtökohtia esimerkiksi tutkimuksille, joissa käsitellään paikan, muistamisen ja materiaalisuuden yhteenliittymiä.

Yleisemmällä tasolla kiinnostava on Turo-Kimmo Lehtosen pohdiskeleva artikkeli "Tyhjä, perusta, paikka. Michel Serres alkamisen ongelmasta", joka käsittelee filosofi Serresin kirjoituksia aluista, kaaoksesta, järjestyksestä ja epäjärjestyksestä. Perinteentutkijoille ja perinne-nimistä ilmiötä ymmärtämään pyrkivälle Lehtosen/Serresin ajatus "perustavaa ei ole järjestys vaan epäjärjestys ja kaaos, joten kiinnostavaa on se, miten jotain saadaan sen keskelle vakautetuksi" (s. 63) on resonoiva. Artikkelissa "arkiseksi" nimetään kaaoksen keskelle järjestyksen tuottamisen pyrkimys, mikä on kiinnostava ajatus esimerkiksi suhteessa siihen, että etnologit usein nimeävät tutkimuskohteensa "arjeksi". Eräs konkreettinen esimerkiksi ihmisten kaaoksenkesytyspyrkimyksistä - siis arkisista merkityksenannoista - tuodaan esille kirjan päättävässä Johanna Mäkelän ja Mari Nivan ruoan puhtautta ja syötävyyttä käsittelevässä hienossa artikkelissa. Artikkeli nivoo kauniisti yhteen niitä merkityksiä, joita ihmiset antavat esimerkiksi kotimaiselle ruoalle. Artikkeli on kirjan muista kirjoituksista hieman erillinen, mutta se liittyy Saarikankaan omien tutkimusten kotia, puhtautta ja likaa (esim. Saarikangas 1998) käsittelevään tematiikkaan. Kaiken kaikkiaan kirjan viimeiseksi valittu artikkeli päättää kokoelman onnistuneesti.

\section{Lopuksi}

Ikkunalla-kokoelma on kokonaisuudessaan hieman polveileva ja juhlakirjojen tapaan aiheeltaan väljä. Tätä artikkelikokoelmaa ei ole kuitenkaan paisuteltu liikaa, ja useat hienot tutkimusartikkelit tekevät siitä jämptin. Vertaisarvioitujen tekstien välissä on joitakin muistelevia ja Saarikankaan henkilö- ja tutkijakuvaa kevyemmällä otteella peilaavia kirjoituksia, joiden anti jää ehkä kuriositeettimaiseksi. Ne sopivat kuitenkin juhlakirjan genreen.

Kirjan otsikossa mainituista käsitteistä sukupuoli jää ehkä yllättävänkin pieneen rooliin ottaen huomion Saarikankaan oman laajan tuotannon aiheen parissa. Syvimmin aihetta käsittelee oikeastaan vain Mieke Balin artikkeli "Looking with women". Tila sen sijaan saa runsaasti huomiota, ja sen myötä toki myös aika, koska näitä ei voi erottaa toisistaan. Folkloristit ehkä harvemmin ovat ensisijaisesti kiinnostuneita tilasta, mutta usea on kiinnostunut nimenomaan ajasta ja sen merkityksistä. Tilan ja ajan yhteenkietoutuneisuuden takia spatiaalisuus on kuitenkin merkityksellinen monitieteinen näkökulma maailmassa olemiseen, ja esimerkiksi myös kehon ja materian tarkasteluissa olennainen. Saarikankaan omien kirjoitusten ja käsillä olevan juhlakirjan kautta on mahdollisuus saada varsin kattava kuva suomenkielisestä humanistisesta tilan tutkimuksesta, ja tällä tutkimuksella on paljon annettavaa myös muille aloille. 


\section{Kirjallisuus}

Aula, Inkeri. 2018. Aistikävely kaupunkimaisemaan: Yhteisen tilan kokemus ja joutomaiden polut. Elore 25(1), 74-95. https://doi.org/10.30666/elore.72816

Korjonen-Kuusipuro, Kristiina ja Anna-Kaisa Kuusisto-Arponen. 2017. Muistelun monet muodot - kertomus, kehollisuus ja hiljaisuus paikan tietämisen tapoina. Elore 24(1), 1-17. https://doi.org/10.30666/elore.79278

Ojanen, Karoliina. 2018. Pysähdyttävät paikat: Videoitu kävelyhaastattelu etnografisena menetelmänä. Elore 25(2), 128-140. https://doi.org/10.30666/elore.76610

Saarikangas, Kirsi. 1998. Suomalaisen kodin likaiset ja paikat. Hygienia ja modernin asunnon muotoutuminen. Tiede \& edistys 23, 198-220.

Saarikangas, Kirsi. 2006. Eletyt tilat ja sukupuoli. Asukkaiden ja ympäristön kulttuurisia kohtaamisia. Helsinki: Suomalaisen Kirjallisuuden Seura.

Savolainen, Ulla, Karina Lukin ja Anne Heimo. 2020. Omaehtoisen muistamisen materiaalisuus ja monimediaisuus: Muistitietotutkimus ja uusmaterialismi. Elore 27(1), 60-84. https:// doi.org/10.30666/elore.89039

Suopajärvi, Tiina, Eerika Koskinen-Koivisto, Kristiina Korjonen-Kuusipuro, Kirsi-Maria Hytönen ja Pilvi Hämeenaho. 2019. Tunteilla on väliä: Tutkijan tunteet etnografisessa tutkimusprosessissa. Elore 26(2), 42-67. https://doi.org/10.30666/elore.77809

Tolvanen, Mika ja Simo Laakkonen. 2018. Kohti vedenpinnan alaista humanistista maisemaa. Moniaistinen sukellus Itämereen. Elore 25(1), 50-73. https://doi.org/10.30666/ elore.72814

Filosofian tohtori ja musiikin maisteri Heidi Haapoja-Mäkelä toimii post doc -tutkijana Helsingin yliopistossa Koneen säätiön rahoittamassa hankkeessa nimeltä "Omistajuus, kieli kulttuuriperintö - Kansanrunousideologiat Suomen, Karjalan tasavallan ja Viron alueilla". 